\title{
Construing construction
}

'I believe that the tower will have its own beauty', declared Gustave Eiffel in an interview with the newspaper Le Temps. 'The first principle of architectural beauty,' he explained, 'is that the essential lines of a construction be determined by a perfect appropriateness to its use.' In this case the primary 'use' was resistance to wind, and in Eiffel's previously untranslated text published here on pp215-245, the 'magician of iron' - as he became known throughout France - discusses in fascinating detail the engineering logic behind his design.

Although Eiffel would no doubt be flattered that his great tower came to bear his name, he would surely have thought it an unpardonable presumption to have referred to it as his rather than - as he does throughout the text - the tower. Until recently the same held true for most architects and students when discussing a building or design. No longer: for increasingly many, everything is 'my' and 'mine'. Such linguistic shifts are frequently revealing, and this one is surely of a piece with the determination to promote an ever more personal and distinctive maniera as a means of colonising a niche in the global marketplace.

At first sight, the zoomorphic surface that looms mysteriously on this issue's cover might appear to be the materialisation of just such a piece of wilfully personal form-making. In fact, as Alan Chandler's paper reveals (pp204-214), it is the product of an inventive fabric formwork that enables concrete to be tuned with that 'perfect appropriateness' to given conditions to which Eiffel aspired - a far cry indeed from the constructional convolutions that are often deployed to realise computer-generated forms.

Given the radical separation between outer form and inner structure necessitated by much modern construction, what Le Corbusier called the 'engineer's aesthetic', grounded in the 'truth' of construction and materials, has become ever more elusive. But without such goals, without the belief in the possibility of apparently objective, and therefore potentially shared, values the discipline of architecture risks descending into arbitrariness. Hence, in part, the emphasis on construction and the 'making' of architecture in several papers in this double-issue.

To many, Frank Gehry's recent work epitomises the growing divorce between conceptual idea and constructional technique, but as Paolo Tombesi suggests in his dissection of Disney Hall in Los Angeles (pp246-259), things are not so straightforward. The seductive skin and complex forms may appear to be a sophisticated, almost self-indulgent, display of digital wizardry - from laser scanning to numerically-controlled cutting. But they are also emphatically a product of the space-making within, and informed by that same delight in industrial materials and low-tech invention that was the hallmark of Gehry's early essays in raw ply, metal siding and chain-link fencing that brought him to international attention. Reflective, analytical criticism of the kind Tombesi offers here has been all but eliminated from the fashion parade of mainstream architectural magazines, and we would welcome more such close readings of buildings.

THE EDITORS 


\section{architectural research quarterly}

\section{Subscribe now}

Innovative in conception, unique in breadth and generously illustrated, this pace-setting quarterly publication from Cambridge University Press links, on a global scale, the worlds of architectural practice and research. arq regularly includes extensive peer-reviewed sections on design, history, theory, construction, environmental design, information technology and practice - as well as structures, urbanism and documents. These are supplemented by letters, reports, reviews, a directory of specialist research centers and consultancies and an annual index. Each issue opens with a leader and closes with insight, a personal end-piece. In its three year history, arq has published work from all over the world: from Chile to Sweden and from Japan to the Netherlands - with a strong representation from the United Kingdom and United States. arq, like architecture itself, is all-embracing and written by and for both practitioners and academics. It provides an outlet for all those who wish to disseminate their work to an international audience.

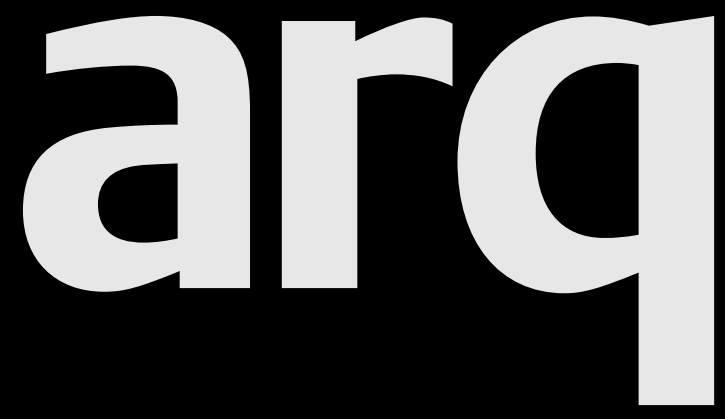

arq: architectural research quarterly, volume 9, 2005

$\square £ 135 / \$ 213$ institutions print and electronic

£28/\$46 students print only

$£ 42 / \$ 64$ individuals print only

EU residents only. VAT may be payable at your local rate if not registered.

Our VAT registration number: GB 214141614 If registered, your VAT registration no:

Total subscription payment $€ / \$$ EU residents only, if not registered add VAT at appropriate rate ${ }^{£}$

Canadian residents, add $7 \%$ GST \$

Total $\mathbf{E} / \$$

Name

Address

Payment enclosed

Cheque in sterling or US dollars

(payable to Cambridge University Press)

Credit Card - VISA | MasterCard | American Express (delete where applicable)

Card no

Expiry date

Signature

Photocopy this page and send your order to:

Journals Customer Services, Cambridge University Press, The Edinburgh Building, Cambridge, CB2 2RU, UK

$\mathrm{T}+44(0) 1223326070$

F $+44(0) 1223315052$

E journals@cambridge.org

or in USA, Canada and Mexico send to:

Cambridge University Press, 4o West 2oth Street,

New York NY 10011-4211, USA

T (914) 9379600

F (914) 9374712

E journals_subscriptions@cup.org 